\title{
Role of Phosphorylation in the Control of Clathrin-Mediated Internalization of GPCR
}

\author{
Frederic Delom $^{1,2}$ and Delphine Fessart ${ }^{1,2}$ \\ ${ }^{1}$ Bordeaux Cardiothoracic Research Center, Bordeaux University, 146, Léo-Saignat, 33076 Bordeaux, France \\ ${ }^{2}$ Inserm U1045, 146, Léo-Saignat, 33076 Bordeaux, France \\ Correspondence should be addressed to Delphine Fessart, delphine.fessart@yahoo.fr
}

Received 28 January 2011; Accepted 1 April 2011

Academic Editor: Michael Hortsch

Copyright ( 2011 F. Delom and D. Fessart. This is an open access article distributed under the Creative Commons Attribution License, which permits unrestricted use, distribution, and reproduction in any medium, provided the original work is properly cited.

The process by which G protein-coupled receptors (GPCRs) are internalized through the clathrin-coated vesicles involves interactions of multifunctional adaptor proteins. These interactions are tightly controlled by phosphorylation and dephosphorylation mechanisms resulting in the regulation of receptor endocytosis. However, the identities of the kinases involved in this process remained largely unknown until recently. This paper discusses advances in our knowledge of the important role played by protein phosphorylation in the regulation of the endocytic machinery and how phosphorylation controls the coated vesicle cycle.

\section{An Overview on G Protein-Coupled Receptors (GPCRs) Internalization}

Reversible protein phosphorylation by the interplay between kinases and phosphatases is a major regulatory mechanism for $\mathrm{G}$ protein-coupled receptors (GPCRs) internalization [1-3]. Therefore, the aim of this paper is to synthesise our understanding of the phosphorylation mechanisms regulating GPCRs internalization. Growing interest in this field is due to the involvement of GPCRs in the regulation of a number of functions. Following their activation, these receptors enter inside the cells, a process named receptor internalization. This process requires receptor desensitization which is achieved by receptor phosphorylation, sequestration and internalization. In this manner, receptors are removed from the surface and transferred into cells. Inside the cells, receptors are embedded into small membrane vesicles (endosomes) which may be recycled back to the plasma membrane in order to renew their fully functional coupling with proteins and effectors (i.e., resensitization). GPCRs expression can also be regulated by a process of downregulation which is a terminal stage of receptor life where receptors are degraded in lysosomes. However, it is now becoming apparent that GPCRs can also be regulated independently of their phosphorylation state (reviewed in
[4]). Before starting the role played by phosphorylation during receptor internalization, a brief review of the different steps controlling receptor internalization will be given.

1.1. Steps Conducting to Receptor Internalization. The current proposed model for GPCRs internalization is essentially based on $\beta 2$-adrenergic receptor ( $\beta 2$-AR) studies. Briefly, following agonist stimulation, GPCRs undergo conformational change that allow binding of $G$ proteins, leading to the activation of different effectors and signaling pathways [5]. The desensitization process is then activated (Figure 1). One of the first steps involves the functional "uncoupling" of the G proteins from the receptors. The receptor is subsequently phosphorylated by $\mathrm{G}$ protein-coupled receptor kinases (GRKs) to enhance the binding of $\beta$-arrestins (step 1 , Figure 1). $\beta$-arrestins act as scaffolding intermediates with components of the clathrin-coated-pit machinery, thus stabilizing association with clathrin-coated pits (CCPs) (steps 2 and 3, Figure 1). The formed pits progressively invaginate and are finally released into the cytosol as a free clathrincoated vesicle (CCV) (step 4, Figure 1), a step which requires the GTPase activity of dynamin to pinch off clathrincoated vesicles from the plasma membrane [6]. After coat assembly and following vesicle scission, all the components 


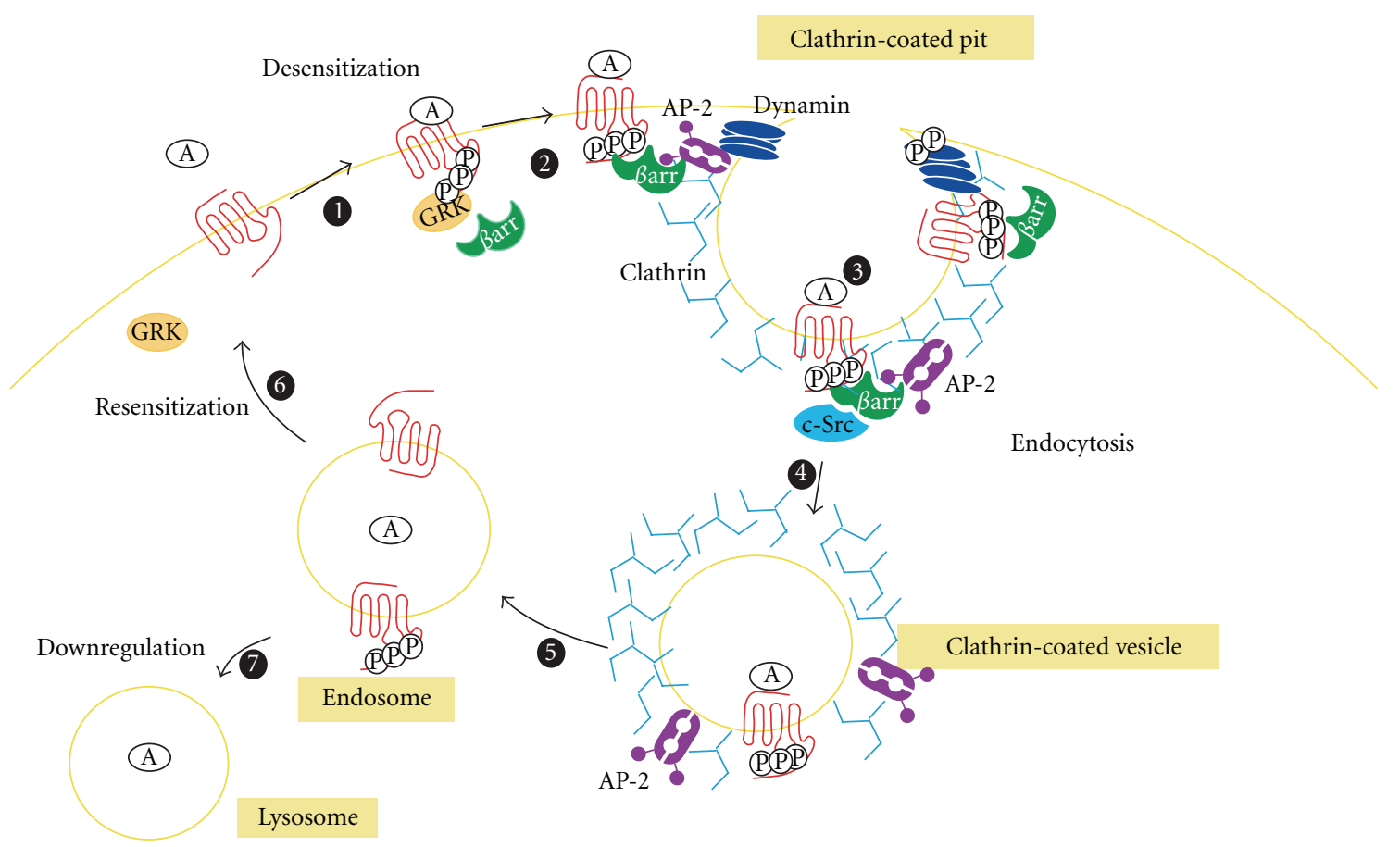

FIGURE 1: Steps conducting to G protein coupled receptors internalization. Internalization and recycling of GPCRs. Upon agonist binding, receptors are phosphorylated (P) by GRKs leading to the recruitment of $\beta$-arrestins (step 1). Beta-arrestins, through their interaction with clathrin and AP-2, target the receptor/arrestin complexes to clathrin coated pits (step 2). Beta-arrestins also bind c-Src (steps 2 and 3 ). Dynamin (step 3), a GTPase, regulates the pinching off from the cell surface of clathrin-coated pits (steps 3 and 4). Once clathrin-coated vesicles are formed (step 4), the receptor is then internalized into endosomes (step 5), dephosphorylated before returning to the cell surface (step 6), or the receptor is degradated to lysosomes (step 7).

must be disassembled so that the CCV can fuse with an early endosome (step 5, Figure 1). The early endosome controls the activity and the destination of proteins in the compartment. Therefore, endosomes are a key control point for sorting receptors, which can be directed to recycling endosomes and back to the cell surface (step 6, Figure 1), or directed to late endosomes or lysosomes for degradation (step 7, Figure 1). Even though several groups have studied GPCRs internalization via the clathrin-coated vesicles, a clear picture of all the phosphorylated proteins involved in this mechanism that regulates GPCRs internalization still remains elusive.

\section{Regulation of GPCRs Internalization by Receptor Phosphorylation}

Following receptor activation by an agonist, the receptor undertakes the process of desensitization, defined as "off switch" of all receptor functions triggered by the agonist at the plasma membrane. Therefore, GPCRs control their own responsiveness to dampen the physiological response to the continued presence of the stimulus [7]. This process is the consequence of a combination of different mechanisms. The cloning of the $\beta 2-\mathrm{AR}$ in 1986 and its shared homology with the rhodopsin receptor [8] allowed the discovery that both receptors become phosphorylated in a stimulus-dependent way and that this phosphorylation seemed to be related to the process of receptor desensitization. Desensitization is thought to be mediated through phosphorylation of serine and threonine residues by $\mathrm{G}$ protein-coupled receptor kinases (GRKs) [9], second messenger-dependent protein kinases such as cAMP-dependent kinase (PKA), and protein kinase C (PKC) [10-14].

2.1. Receptor Phosphorylation by Second Messengers: Heterologous Desensitization. PKA and PKC are phosphotransferases that catalyze the transfer of the $\gamma$-phosphate group of ATP to serine and threonine residues contained within specific amino acid consensus sequences of proteins. They can phosphorylate a receptor even in the absence of its agonist, resulting in "heterologous" desensitization (reviewed in [15]). These kinases are activated in response to GPCRsstimulated increases in intracellular second messengers, such as cAMP, $\mathrm{Ca}^{2+}$ and diacylglycerol (DAG), and participate in GPCRs signaling by mediating the phosphorylation of the receptor itself or other downstream target proteins. In the latter case, receptors that have not been activated by a ligand may become desensitized by activation of these kinases. PKAmediated receptor phosphorylation has also been shown, in the case of the $\beta 2-\mathrm{AR}$, to switch coupling of the receptor away from $\mathrm{G}_{s}$ in favour of enhanced coupling to $\mathrm{G}_{i}$ [16]. Several other receptors, including the prostacyclin receptor, also seem to undergo such PKA-mediated switching in their G protein-coupling specificity [17]. The phosphorylation 
of GPCRs by PKA and PKC has also been shown for other receptors such as gamma-aminobutyric acid receptor type $B\left(\mathrm{GABA}_{B}\right)[18,19]$. In addition to these kinases, the 5 AMP-dependent kinase (AMPK), a serine/threonine protein kinase, has been shown to phosphorylate $G_{A B A}$ receptor on Ser-783 to further decrease receptor desensitisation [20].

\subsection{Receptor Phosphorylation by G Protein-Coupled Receptor} Kinases (GRKs): Homologous Desensitization. By the mid1980s, it had become clear that both rhodopsin [21] and the $\beta 2$-AR [22] were phosphorylated in a stimulus-dependent way, and that this phosphorylation seemed to be related to receptor inactivation or desensitization. In the case of rhodopsin, the enzyme responsible for the phosphorylation was referred to as rhodopsin kinase [23]. In the case of the $\beta 2$-AR, a novel cAMP-independent kinase [called the $\beta$ adrenergic receptor kinase $(\beta \mathrm{ARK})]$ appeared to contribute to agonist-dependent phosphorylation of the receptor [24]. Now, 7TM receptors (GPCRs) are traditionally thought to signal by means of activation of heterotrimeric $G$ proteins and then to be desensitized by GRKs which are recruited to and specifically phosphorylate only agonist-occupied receptors leading to "homologous desensitization" [24, 25].

2.2.1. GRK Family. GRKs phosphorylate GPCRs at both serine and threonine residues localized within the third intracellular loop (i3) or C-terminal tail domain [26]. Although no putative GRK phosphorylation consensus motifs have been identified, localization of amino acidic residues flanking repeated serines/threonines to the site of phosphorylation seems to favour GRK-2-mediated phosphorylation [27]. So far, only GRKs selectively phosphorylate agonist-activated receptors, whereas second messenger-dependent kinases can phosphorylate receptors in the presence or absence of an agonist. Seven mammalian GRK genes have been identified, some of which undergo alternative splicing to generate different isoforms $[26,28]$. The GRKs consist of three distinct domains: the kinase domain, the N-terminal RGS (regulator of $\mathrm{G}$ protein signaling) domain, and the Cterminal domain which contributes to the plasma membrane targeting of the kinase. The function of RGS proteins is to inhibit the activity of the $\mathrm{G} \alpha$-subunit by acting as GTPaseactivating proteins (GAPs) [29]. The specificity of GRKs in vitro has not yet been defined, but tissue distribution, as well as levels of expression, probably contributes to their specificity in vivo [30-32]. However, studies show that different GRKs induce distinct signaling upon Angiotensin II type 1 receptor (AT1R) or V2 vasopressin receptor (V2R) activation, and suggest that GRK-2 and -3 will antagonize the effects of GRK-5 and $-6[33,34]$. Several factors control the activity of the kinases towards the receptors. Principally, the activated conformations of the receptors themselves activate the enzymes [31].

2.2.2. GRK Phosphorylation to Regulate its Own Activity. A regulatory complexity is added by the fact that GRK activity can be influenced by phosphorylation. Mitogen-activated protein kinase (MAPK) decreases its efficacy towards GPCRs substrates [35], whereas both PKA and PKC can phosphorylate and activate GRK-2 by promoting its $\mathrm{G} \beta \gamma$-mediated membrane association $[36,37]$ and potentiating its activity $[36,38]$. In contrast, GRK-5 activity can be influenced by phosphorylation of PKC kinase to reduce its activity [39]. Moreover, c-Src, via its recruitment to the agonist-dependent binding of $\beta$-arrestin to GPCRs, phosphorylates GRK-2 on tyrosine residues and targets GRK-2 for degradation $[40,41]$.

\subsubsection{GRK Phosphorylation of Receptors for $\beta$-Arrestin} Recruitment. GRK-phosphorylation of receptors is not sufficient for desensitization, but rather serves to create high affinity sites to promote the recruitment of the cytoplasmic accessory proteins, arrestins, and target the receptors for internalization via clathrin-coated pits. The arrestin protein was first identified by Wilden et al. in 1986 as, "a 48K protein", bound to the phosphorylated rhodopsin, thereby interfering with its coupling to transducin [42]. The protein was later renamed arrestin [43]. Therefore, it was postulated that the GRK-mediated phosphorylation of clusters of serine and threonine residues in the C-terminal tails of some receptors may regulate the stability of receptor/arrestin complexes [44]. For most receptors, the determining factor for $\beta$-arrestin interaction is the phosphorylation status of the activated GPCRs. Thus, impairment of receptor phosphorylation by mutagenesis of key serine/threonine residues generally leads to diminished $\beta$-arrestin binding after stimulation of the M2 muscarinic cholinergic receptor, rhodopsin, the AT1R, or the V2R [45-48]. The arrestins recruitment in turn induces desensitization by preventing further coupling to $G$ proteins $[49,50]$. However, there are some exceptions and widespread variations against a general model of receptor phosphorylation in the regulation of internalization. For example, the findings that mutants of the parathyroid hormone receptor underwent endocytosis in the absence of detectable agonist-induced phosphorylation [51]. In addition, Richardson et al., [52] have shown that substance $\mathrm{P}$ receptor lacking the $\mathrm{C}$-terminal domain remains competent to desensitize and internalize. These and similar data obtained with a truncated opioid receptor [53] or with the leukotriene B4 receptor 1 (BLT1) [54] do not support a general role for receptor phosphorylation in the control of GPCRs internalization. Overall, these findings led Kim et al. to suggest that the role of receptor phosphorylation allow the access of arrestin to its receptor binding domain than to create an arrestin-binding site [55].

\subsection{Receptor Phosphorylation by Casein Kinase II (CK2).} Casein kinase II has been reported to phosphorylate the M3-muscarinic receptor in cerebella granule neurons and to affect coupling to the Jun-kinase pathway [56]. It was also suggested that 3 putative CK2 phosphorylation sites on the carboxyl tail of the TSH-releasing hormone receptor (TRHR) were important for its internalization [57]. In addition to TRHR receptor, the Leukotriene B4 receptor ( $\mathrm{G} \alpha_{0}$-coupled) contains also a putative CK2 site, which, when mutated, reduced GRK-6-mediated desensitization [58]. Rebholz et al. 
have suggested that GPCRs regulation by CK2 is exerted through its ability to enable faster endocytosis of $\mathrm{G}_{s}$-coupled receptors [59]. However, it remains unclear if this type of phosphorylation is common to others GPCRs family members.

\section{Regulation of GPCRs Internalization by Arrestin Phosphorylation}

Despite numerous studies suggesting an essential role of arrestins in GPCRs regulation, the detailed mechanism underlying the function of arrestins and receptor-mediated modulation of arrestin activity is unclear. $\beta$-Arrestin are component of a multiprotein complex that assembles on the receptor after ligand stimulation. Acting as a protein scaffold, it recruits Src kinase and also binds to clathrin, and adaptor-protein 2 (AP-2), which serves to target the activated GPCRs to clathrin-coated pits for internalization. $\beta$-Arrestin also induce rapid homologous desensitization of the receptor by binding to the GPCRs and sterically inhibiting further G-protein coupling. However, several reports on arrestin phosphorylation provide some insight into potential regulation of arrestin function.

3.1. Arrestin Phosphorylation by Extracellular Signal-Regulated Kinases 1 and 2 (ERK1/2). Studies on mammalian $\beta$ arrestin 1 demonstrate that $\beta$-arrestin 1 was constitutively phosphorylated at Ser-412 by extracellular signal-regulated kinases 1 and 2 and became dephosphorylated following $\beta_{2}$ AR stimulation $[60,61]$. $\beta$-arrestin 1 phosphorylation was proposed to regulate the interaction of arrestin with clathrin and Src, since a S412D mutant mimicking phosphorylated $\beta$-arrestin 1 had reduced binding to these proteins [60, 62]. Thus, agonist treatment of GPCRs, which induces dephosphorylation of $\beta$-arrestin 1 at Ser-412, as well as transfection of the S412A $\beta$-arrestin 1 mutant, which mimics dephosphorylated $\beta$-arrestin 1 and enhances clathrin and Src binding to $\beta$-arrestin 1 , resulting in enhanced GPCRs internalization. Notably, $\beta$-arrestin 2 shares $\sim 80 \%$ amino acid identity with $\beta$-arrestin 1 but does not contain the corresponding serine residue. Thus, $\beta$-arrestin 2 might be phosphorylated at other sites or perhaps be regulated by different mechanisms.

3.2. Arrestin Phosphorylation by GRK. Recently, $\beta$-arrestin 1 has also been shown to be phosphorylated at Ser-412 by GRK-5 [63]. This phosphorylation, in turn, prevents the activation of c-Src and, therefore, blocks ERK signalling.

3.3. Arrestin Phosphorylation by CK2. Kim et al. have reported that $\beta$-arrestin 2 is constitutively phosphorylated by casein kinase II at Thr-383 and suggested that $\beta$-arrestin 2 phosphorylation may regulate its interaction with novel binding partners unidentified [64]. Threonine 383 is the primary phosphorylation site, and serine 361 represents a secondary site $[64,65]$. Dephosphorylation of $\beta$-arrestins at the plasma membrane seems to be necessary for engaging endocytic partners.
3.4. Arrestin Phosphorylation by Calcium/Calmodulin-Dependent Kinase II (CaMKII). In Drosophila, two visual system arrestins have been identified: Arr1 and Arr2. Both Arr1 and Arr2 are phosphorylated in a light-dependent manner, and it has been established that Arr2 is phosphorylated by a $\mathrm{Ca}^{2+} /$ calmodulin-dependent protein kinase (CaMKII) [66]. Although it has been known for quite some time that Arr2 is phosphorylated in a light-dependent manner, it is unclear just what role this phosphorylation serves. Studies with Drosophila visual arrestin-2 demonstrate that it undergoes light-dependent phosphorylation by calcium/calmodulindependent kinase II and that phosphorylation is necessary for dissociation of arrestin from rhodopsin [67, 68]. It has been proposed that the calcium- and light-dependent phosphorylation of Arr2 acts as the signal to bind and inactivate metarhodopsin, and therefore, Arr2 phosphorylation serves to modulate the inactivation of the signaling cascade [66, 69-71]. However, recent evidence suggest that the phosphorylation of Arr2 is also necessary for its release from membranes once rhodopsin has been photoconverted back to its inactive form [68].

3.5. Arrestin Phosphorylation by Src. Src kinases phosphorylates tyrosine residues on the clathrin coated pit structural proteins including clathrin itself and dynamin but also $\beta$ arrestin. There are four tyrosines present in the $\mathrm{N}$-terminall part of $\beta$-arrestin- 1 that are not conserved in $\beta$-arrestin- 2 [72]. One of these residues is Tyr-54 which is phosphorylated by Src, and a single point mutation Y54F is sufficient to prevent its phosphorylation. The constitutive substitution of $\beta$-arrestin- 1 tyrosine 54 by phenylalanine increases the $\beta$ arrestin- 1 interaction with the $\mu$-subunit of the AP-2 and enhances $\beta$-arrestin-1-mediated $\beta 2$-AR internalization.

Furthemore, $\beta$-arrestin has been shown recently to mediate phosphorylation events by activating 38 protein kinases [73]. However, it remains unclear if this effect is correlated with the $\beta$-arrestin-phosphorylation status.

\section{Regulation of GPCRs Internalization by Clathrin Phosphorylation}

Clathrin is also subject to phosphorylation both in vitro and in vivo and are thought to serve as regulatory subunits $[74,75]$. The very limited data on this suggest that the phosphorylation of clathrin could be inhibitory for coat assembly $[76,77]$.

4.1. Clathrin Phosphorylation by c-Src. Tyrosine phosphorylation of clathrin was shown only for the epidermal growth factor receptor. Tyrosine phosphorylation of the clathrin heavy chain by Src-family kinases enhances the clathrin recruitment to the plasma membrane. It was shown that ligand binding to the epidermal growth factor receptor leads, via activation of protein kinase activity, to clathrin phosphorylation [78].

4.2. Clathrin Phosphorylation by CK2. Casein kinase 2 plays an essential role in endocytosis, the inhibition of CK2 leads 
to a significant decrease in transferrin uptake [79]. CK2 is highly enriched in CCV preparations and phosphorylates the clathrin light chain in vitro [75]. As mentioned above, the clathrin light chain is also found to be phosphorylated in vivo, but the functional role of this phosphorylation event in endocytosis is not entirely clear.

\section{Regulation of GPCRs Internalization by Adaptor Proteins (AP)}

Clathrin-mediated endocytosis is the well-described mechanism for the entry of molecules into cells. This pathway is characterized by the recruitment of soluble clathrin from the cytoplasm to the plasma membrane. Clathrin-binding adaptors, such as the adaptor-protein 2 (AP-2), are the key components of this pathway. They bind directly to clathrin [80], as well as $\beta$-arrestin and other endocytic regulatory proteins to stimulate the formation of the clathrin coat [81]. In this model, the clathrin adaptor complex AP-2 plays a central role in CCP formation and function, being responsible for the assembly of clathrin triskelia at the plasma membrane and selection of cargo receptors that will be internalized by forming CCVs. AP-2 is a heterotetramer composed of two large subunits ( $\alpha$-adaptin and $\beta 2$-adaptin), a medium subunit $(\mu 2)$, and a small subunit $(\sigma 2)$. It has been known for some time that several proteins associated with clathrincoated vesicles are substrates for protein kinases. These proteins include AP-2, dynamin, clathrin, synaptojanin 1, and amphiphysins. However, the identities of the kinases involved in this process remained largely unknown until recently. So far, only three of the four adaptor complex subunits of AP-2 have been shown to be phosphorylated.

\subsection{Serine/Threonine Phosphorylation of the $\mu 2$-Subunit of} $A P-2$ by Cyclin G-Associated Protein Kinase (GAK). It has been known for many years that $\mu 2$ is phosphorylated both in vivo, and in vitro but the functional relevance of these posttranslational modifications was unclear [82]. The identity of the kinase that phosphorylates $\mu 2$ remained obscure for a long time. Two candidate kinases have been described in the literature [83-88]. One of them, termed GAK (for cyclin G-associated protein kinase), was shown to phosphorylate $\mu 2$ recombinant proteins in vitro [86]. It was also demonstrated that GAK copurifies with CCVs, and that immunoprecipitated GAK can phosphorylate the endogenous $\mu 2$ subunit in vitro [85]. GAK is a complex protein; in addition to an N-terminal kinase domain, it contains a central tensin homology domain and a C-terminal J domain. This C-terminal domain shows similarity to auxilin, a neuronal protein that facilitates Hsc70 in the uncoating of CCVs. Hence, an alternative (and possibly more appropriate) name for GAK is auxilin 2 [87]. GAK was shown to bind directly to both clathrin and the appendage domain of $\alpha$-adaptin [86]. GAK/auxilin 2 is localized mostly to the trans-Golgi network (in HeLa cells at least). However, its overexpression completely prevents transferrin uptake $[86,87,89]$ implying a role for GAK/auxilin 2 in endocytosis. Given the multifunctional nature of GAK/auxilin 2, it is presently difficult to conclude whether the effect of GAK/auxilin 2 overexpression on endocytosis is due to its role in clathrin uncoating or $\mu 2$ phosphorylation.

5.2. Serine/Threonine Phosphorylation of the $\mu 2$-Subunit of AP-2 by $\alpha$-Adaptin-Associated Kinase-1 (AAK1). It was shown, in vitro, that $\mu 2$ phosphorylation is required for internalization of Transferrin receptor [90]. However, with the identification of Thr-156 as a residue essential for clathrin-coated pit function in vivo $[83,84]$, it appears clearly that phosphorylation play an important role in endocytosis. Several studies indicate that the phosphorylation of Thr156 on $\mu 2$-subunit induced by $\alpha$-adaptin-associated kinase1 (AAK1), could regulate its binding to endocytic cargo [83, 84, 91]. AAK1 was identified using a phage display library screening strategy [84]. Just like GAK/auxilin 2, AAK1 is enriched in purified CCV preparations and phosphorylates the $\mu 2$ subunit of AP-2 in vitro [84]. Although some observations have demonstrated that the $\mu 2$ phosphorylation is not obligatory for receptor uptake, it is critical for maximizing internalization efficiency $[90,92]$. Additionally, serine/threonine phosphorylation of AP-2 in the hinge region, between the $\mathrm{C}$-terminal ear and the $\mathrm{N}$-terminal domains of the beta-subunit, has been shown to affect AP2's ability to interact with clathrin and to associate with membranes [74]. Thus, phosphorylation of AP-2 complexes regulates their recruitment to the plasma membrane [93], their interaction with cargo molecules containing tyrosinesorting signals [83], and their assembly with clathrin [74, 94].

5.3. Phosphorylation of $\alpha$ - and $\beta 2$-Subunits of $A P-2$ by CK2. It was found that Casein kinase 2 (CK2) phosphorylates the $\alpha-$ and $\beta 2$-subunits of the AP-2 adaptor complex in vitro [85]. It is possible that CK2 plays the same role in vivo. In vitro phosphorylation of AP- 2 by CK 2 prevents AP- 2 from binding to clathrin cages, thus mimicking the effect observed in vivo [74].

5.4. Tyrosine Phosphorylation of $\beta 2$-Subunit of AP-2 by Src. The list of GPCRs-activated signaling pathways in which $\beta$ arrestins have been implicated includes not only components of the clathrin-endocytic machinery, but also signaling molecules such as the non-receptor tyrosine kinase Src family [95-101]. Src family kinases exhibit a highly conserved structural organization that includes a myristoylated $\mathrm{N}$ terminal domain to facilitate its attachment at the plasma membrane, followed by the $\mathrm{SH} 3$ domain recognizing a proline-rich region, the $\mathrm{SH} 2$ domain recognizing tyrosine phosphorylated residues, the tyrosine kinase domain ( $\mathrm{SH} 1$ ) and a C-terminal tail [102]. Thus, targeting of Src family kinase is accomplished through protein-protein interactions involving the phosphotyrosine-binding Src homology domain 2 ( $\mathrm{SH} 2$ ) and proline-rich domain-binding $\mathrm{SH} 3$ domains common to all members of the family. Today, c-Src is described as an important regulator of GPCRs endocytosis based on MEF cells deficient of Src-family tyrosine kinases (SYF cells), where the internalization of $\beta 2 \mathrm{AR}$ was abolished [103]. Upon stimulation of the $\beta 2 \mathrm{AR}, \mathrm{c}-\mathrm{Src}$ rapidly associates 
with the receptor in a $\beta$-arrestin-dependent manner [62]. c-Src mutants devoid of catalytic activity that can interact with $\beta$-arrestin (SH1-KD) function as dominant-negative inhibitors of clathrin-mediated internalization of receptors $[100,104]$. Also, several new substrates for the c-Src phosphorylation of proteins involved in the endocytic machinery have been identified (see Table 1).

It has been suggested that $\mathrm{c}$-Src recruitment to the endocytic complexes may play a role in the activation of the endocytic machinery $[78,100,101]$. This has been confirmed by Fessart et al. that the recruitment of Src to the $\beta$-arrestin/AP-2 complex is necessary for the agonistdependent phosphorylation of the $\beta 2$-subunit on Tyr-737, and regulates the disassembly of the endocytic complex and AT1R internalization [105]. This mechanism has been demonstrated for other GPCRs like the $\beta 2$-adrenergic, vasopressin V2, bradykinin type 2, platelet-activating factor, and endothelin A receptors but also for other type of receptors such as epidermal growth factor receptor [106].

\section{Regulation of GPCRs Internalization by Dynamin Phosphorylation}

During receptor internalization, it was initially thought that $\beta$-arrestin participated in the de novo formation of CCPs $[107,108]$. However, recent evidence shows that $\beta$ arrestin targets receptors to existing pits at the cell surface and engage them in the internalization process $[109,110]$. Although this issue remains controversial, the general model for receptor internalization from the plasma membrane is that the formed pits progressively invaginate and are finally released into the cytosol as free CCV, a step which requires the activity of dynamin. Dynamin is a GTPase involved in the pinching off of clathrin-coated vesicles from the plasma membrane [6].

6.1. Dynamin Phosphorylation by c-Src. Dynamin is regulated by tyrosine phosphorylation during $\beta 2$-AR internalization. The proposed model is that $\beta$-arrestin will act as an adaptor/scaffold to bind c-Src, allowing the phosphorylation of dynamin [100]. Ahn and collaborators identified two tyrosines $(\mathrm{Y} 231 \mathrm{~F} / \mathrm{Y} 597 \mathrm{~F})$ in dynamin that, when mutated, cannot be tyrosine phosphorylated by c-Src, and thus inhibit the agonist-induced internalization of the $\beta 2$-AR. These data were also confirmed for the M1 muscarinic receptor [111], suggesting that tyrosine phosphorylation of dynamin plays an important role in endocytosis. Recently, Src kinase activity has been shown to regulate the endocytosis of the transferrin by phosphorylating two important components of the endocytic machinery, namely, the large GTPase dynamin 2 (Dyn2) and its associated actin-binding protein, cortactin (Cort) [112]. Src phosphorylation of dynamin seems also to act to increase both dynamin self-assembly and GTPase activity [113].

6.2. Dynamin Phosphorylation by Protein Kinase C (PKC). Dynamin I is also phosphorylated by protein kinase $\mathrm{C}$ in vitro and probably by PKC in intact nerve terminals [114-117].
Dynamin I is then dephosphorylated by the $\mathrm{Ca}^{2+}$-dependent phosphatase calcineurin in vitro and in nerve terminals [118121]. After dephosphorylation, dynamin I is fully rephosphorylated within 2 min $[114,122]$. Rephosphorylation can be inhibited with a range of low-specificity PKC antagonists, suggesting that $\mathrm{PKC}$ is the dynamin I kinase in nerve terminals [114]. This PKC-mediated phosphorylation of dynamin has been proposed as a mechanism to remove dynamin I from the plasma membrane to a cytosolic compartment, where it is appropriately localized to participate in the next cycle of endocytosis [123].

6.3. Dynamin Phosphorylation by Cyclin-Dependent Kinase 5 (Cdk5). Although several kinases for dynamin have been reported based on in vitro studies, Cdk5 has recently been reported to phosphorylate dynamin both in vivo and in vitro, and the phosphorylation sites have been determined. Cdk5 is one of the proline-directed kinases and phosphorylates serine/threonine motifs [124]. Cdk5 phosphorylates Thr780 in dynamin 1 [125]. The phosphorylation of dynamin reduces its ability to interact with the amphiphysin 1 .

\section{Regulation of GPCRs Internalization by Synaptojanin 1 Phosphorylation}

Synaptojanin 1 is a presynaptic inositol 5-phophatase enriched on endocytic intermediates [126]. As mentioned previously, synaptojanin is also found to be phosphorylated in vivo [127], but the functional role of this phosphorylation event in endocytosis remains to be determined.

\section{Regulation of GPCRs Internalization by Amphiphysin Phosphorylation}

Amphiphysin dimer binds both dynamin and Synaptojanin 1 [128-130]. Disruption of these interaction blocks clathrinmediated endocytosis at the step of invaginated coated pits [131]. The amphiphysin also binds to clathrin and to the $\alpha$-subunit of AP-2 $[131,132]$. The phosphorylation of amphiphysin affects its binding to AP-2. Thus, this complex formation is inhibited by phosphorylation [127]. At least 3 protein kinases have been shown to phosphorylate amphiphysin I: Cdk5, MAPK/ERK and CK2.

8.1. Amphiphysin Phosphorylation by Cyclin-Dependent Kinase 5 (Cdk5). Cdk5 has recently been reported also to phosphorylate amphiphysin 1 in vivo and in vitro, and the phosphorylation sites have been determined. Cdk5 phosphorylates Ser- residues 261, 272, 276, and 285 and Thr310 in amphiphysin 1 [125]. The phosphorylation at these sites is important for regulating the interactions of amphiphysin I with its endocytic partners, clathrin, AP2, endophilin and lipid membrane. Cdk5 has multiple functions in neurons, implicated in the regulation of a range of cellular processes from adhesion and motility to synaptic plasticity and drug addiction $[124,133]$. Cdk5 is abundant in presynaptic terminals in mature neurons [134]. The simultaneous phosphorylation of both amphiphysin I 
TABLE 1: Functional role of phosphorylation by Protein Kinase(s) in vitro and in vivo during clathrin-mediated internalization.

\begin{tabular}{|c|c|c|c|}
\hline Phosphorylation substrates & Kinase & Possible roles & References \\
\hline Dynamin [Tyr-231 Tyr-597] & $\mathrm{Src}$ & & {$[100]$} \\
\hline Dynamin & PKC & stimulates GTPase activity & {$[115]$} \\
\hline Dynamin [Thr-780] & Cdk5 & $\begin{array}{l}\text { Inhibition of Amphiphysin } \\
\text { binding }\end{array}$ & {$[125]$} \\
\hline Angiotensin II type 1 receptor & Src & & {$[143]$} \\
\hline$\beta 2-\mathrm{AR}$, prostacyclin receptor & PKA & switch coupling from $\mathrm{G}_{s}$ to $\mathrm{G}_{i}$ & {$[16,17]$} \\
\hline GPCRs [Ser/Thr] clusters & GRKs & $\begin{array}{c}\text { Desensitization, recruitment of } \\
\text { arrestins }\end{array}$ & {$[26]$} \\
\hline $\mathrm{AP}-2[\mu(\mathrm{Yxx} \Phi)]$ & AAK1 & TfR endocytosis & {$[144]$} \\
\hline AP-2 $[\mu(\mathrm{Yxx} \Phi)]$ & AAK1 & $\alpha$ la AR endocytosis & {$[145]$} \\
\hline AP-2 & AAK1 & binding to endocytic cargo & {$[83,84]$} \\
\hline AP-2 $[\mu]$ & GAK & & {$[85,86]$} \\
\hline $\mathrm{AP}-2[\alpha]$ & CK2 & Inhibition of clathrin binding & {$[74,77]$} \\
\hline AP-2 $[\beta]$ & CK2 & Inhibition of clathrin binding & {$[74,77]$} \\
\hline AP-2 [ $\beta][$ Tyr-737] & c-Src & Inhibition of arrestin binding & {$[105]$} \\
\hline GRK2 & PKC & Increase GRK activity & {$[36,38]$} \\
\hline GRK5 & PKC & Decrease GRK activity & [39] \\
\hline GRK2 & c-Src & targets GRK2 for degradation & {$[40,41]$} \\
\hline$\beta$-arrestin $1[$ Ser-412] & ERK1,2 & $\begin{array}{l}\text { Reduce binding to Src and } \\
\text { clathrin }\end{array}$ & {$[60,61]$} \\
\hline$\beta$-arrestin $1[$ Ser-412] & GRK5 & Block Src activation & {$[63]$} \\
\hline$\beta$-arrestin 1 [Tyr-54] & Src & $\begin{array}{l}\text { Decrease the interaction with the } \\
\qquad \mu \text {-adaptin }\end{array}$ & {$[72]$} \\
\hline$\beta$-arrestin $2[$ Thr-383, Ser-361] & $\begin{array}{l}\text { casein kinase } \\
\text { II }\end{array}$ & $\begin{array}{l}\text { interaction with unidentified } \\
\text { binding partners }\end{array}$ & {$[64,65]$} \\
\hline Arr2 & CaMKII & Unknown & {$[66]$} \\
\hline Clathrin heavy chain & Src & Facilitates membrane binding & {$[78]$} \\
\hline Clathrin Light chain & CK2 & Unknown & [75] \\
\hline Amphiphysin [Thr-350,-387] & $\mathrm{CK} 2$ & $\begin{array}{l}\text { CK2 inhibits interaction with } \\
\text { AP-2 and clathrin }\end{array}$ & $\begin{array}{c}{[127,136} \\
146]\end{array}$ \\
\hline $\begin{array}{l}\text { Amphiphysin [Ser-261, 272, 276, } \\
285 \text { and Thr-310] }\end{array}$ & Cdk5 & $\begin{array}{l}\text { Inhibits interaction with the } \\
\text { beta-subunit of AP-2 }\end{array}$ & {$[125]$} \\
\hline Amphiphysin & MAPK/ERK & Inhibits interaction with AP-2 & {$[135]$} \\
\hline Synaptojanin & PKC & $\begin{array}{l}\text { Inhibits interaction with binding } \\
\text { partners }\end{array}$ & {$[123,127]$} \\
\hline Synaptotagmin & CaMKII & Probably inhibitory & {$[87]$} \\
\hline Epsin & Unknown & $\begin{array}{l}\text { Inhibits interaction with binding } \\
\text { partners }\end{array}$ & {$[147]$} \\
\hline Eps15 & Unknown & Inhibits interaction with AP-2 & [147] \\
\hline
\end{tabular}

and dynamin I inhibits synaptic vesicle endocytosis through inhibition of the association of these proteins with their partner proteins such as $\beta$-adaptin [125]. Therefore, it is possible that the phosphorylation directly regulates the intramolecular interaction in amphiphysin, which in turn regulates the interaction with dynamin.

8.2. Amphiphysin Phosphorylation by Mitogen-Activated Protein Kinase/Extra-Cellular-Signal-Regulated Kinase (MAPK/ $E R K)$. As a second kinase, mitogen-activated protein kinase/ extra-cellular-signal-regulated kinase has been shown to phosphorylate Amphiphysin I at two sites, also within the proline/arginine rich domain (PRD) but distinct from those for cdk5. MAPK/ERK phosphorylates amphiphysin I at Ser285 and Ser-293. This phosphorylation negatively regulates the amphiphysin binding to AP-2 [135].

8.3. Amphiphysin Phosphorylation by CK2. Phosphorylation of amphiphysin-1 can regulate its interaction with the heavy chain of clathrin. This interaction is mediated by two clathrin binding motifs of amphiphysin, the clathrin box and the $\mathrm{W}$ box. Two threonine residues, conserved in amphiphysin-1 and -2, are among several vertebrate species that can be phosphorylated by CK2. The phosphorylation 
of Thr-350 and Thr-387 in amphiphysin by CK2 regulates the interaction of amphiphysin and clathrin [136].

\section{Different Roles of Proteins Phosphorylation}

Coated vesicle formation is a constitutive process that involves continuous cycling of the coat proteins from the cytosol onto the membrane. Reversible phosphorylation is, therefore, a plausible mechanism for how this might be regulated. Phosphorylation events can be classified into two functionally opposite classes: (i) those that are inhibitory for $\mathrm{CCV}$ formation and (ii) those that facilitate the assembly of CCVs.

Few examples of phosphorylation mechanisms occurring during GPCRs internalization were previously reported (see Table 1). Indeed, dynamin was shown to be tyrosine phosphorylated and to regulate $\beta 2-\mathrm{AR}$ internalization [100]. Interestingly, Fessart et al. found that activation of AT1R promotes the tyrosine phosphorylation of the $\beta 2$-subunit of AP-2, to regulate its interaction with $\beta$-arrestin $[101,105]$. Probably another best characterized example is phosphorylation in the hinge region of the $\alpha$ - and $\beta 2$-subunits of the AP-2 complex. Phosphorylated AP-2 has a reduced ability to interact with clathrin and requires dephosphorylation for efficient interaction $[74,77]$. Phosphorylation also appears to be important in modulating the function of several other proteins implicated in endocytosis; these include dynamin 1, clathrin, amphiphysins 1 and 2, AP-180, synaptojanin, epsin and Eps15. These proteins are found to be phosphorylated in resting nerve terminals and dephosphorylated when stimulation invokes a burst of CCV formation [123]. It was shown that phosphorylation of dynamin 1 and synaptojanin 1 inhibits their binding to amphiphysin, while phosphorylated amphiphysin has an impaired affinity for AP-2 and clathrin [127]. For example, in vitro dephosphorylation of rat brain extracts apparently promotes the assembly of dynamin I, synaptojanin, amphiphysin, clathrin, and AP-2 into complexes [127].

The other angle of the story that would be particularly interesting is the in vivo roles of dissociation. In others words, how and why these endocytic complexes dissociate? Close examination of AP-1 [137] and $\beta$-arrestin [65] shows that an effective way of regulating compartmental specificity could be dephosphorylation or phosphorylation by phosphatases and kinases restricted to defined membrane regions. These focal posttranslational modifications could modulate the avidity between network members, promoting assembly (and disassembly) of sorting lattices only at the appropriate location and time. For example, it has been reported that Ark1p (standing for actin regulating kinase 1)/Prk1p (standing for p53 regulating kinase 1)-mediated phosphorylation of a $S$. cerevisiae endocytic, eps15-like accessory factor governs the post budding inactivation of Arp2/3-dependent actin polymerization, preparing the transport vesicle for subsequent fusion [138]. The role of protein phosphorylation in controlling clathrin-coated vesicle formation at the cell surface remains relatively unexplored.
Another explanation is that phosphorylation could also promote the recruitment of new interacting proteins with a SH2 domain. Nevertheless, proof of this model will require crystallization of the phosphorylated endocytic complexes. For example, since the crystal structure was obtained for $\beta 2$-adaptin [139], it will be important in future studies to examine the crystal structure of wild-type $\beta 2$-adaptin as compared to phosphorylated $\beta 2$-adaptin. A structural approach will be useful in demonstrating the ability of phosphorylated $\beta 2$-adaptin to bind, or not, endocytic proteins. It is not unlikely that a protein with an $\mathrm{SH} 2$ domain would make an excellent binding partner for c-Src phosphorylated tyrosine residue within $\beta 2$-adaptin. Other AP-2 subunits when phosphorylated increase their affinity for different proteins. The affinity of phosphorylated $\mu 2$ for peptides containing the tyrosine-containing internalization motif in the cytoplasmic tails of receptors has been shown to be much greater that of unphosphorylate $\mu 2$. Recent structural data on AP-2 suggest a possible molecular explanation for these observations. Apparently, the binding site in $\mu 2$ for the tyrosine-containing motif is buried in the AP- 2 complex, thus a conformational change is required for its exposure. This could be triggered by phosphorylation of $\mu 2$ [140]. In parallel, to verify and identify new proteins interacting with phosphorylated endocytic proteins, a proteomic approach would inform us on the partner(s) recruited during GPCRs endocytosis.

How endocytic phosphorylation cycles are regulated is an important question for the future. Further studies on regulatory inputs and control mechanisms will provide important insight into the events controlling receptor endocytosis.

\section{Futures Prospects in Phosphorylation and Internalization}

While the mechanisms involved in regulating the clathrinmediated endocytic pathway are not fully understood, accumulating evidence suggests that phosphorylation cycles may be a key step $[127,141]$. Indeed, phosphorylation of the clathrin heavy chain [78] and the large and medium subunits of AP-2 $[74,142]$ have been demonstrated to be important to the clathrin-mediated internalization of growth factors and nutrients, respectively. However, the phosphorylation of endocytic factors is not limited to the major coat components. Many others constituents of the endocytic machinery including dynamin1, amphiphysin 1 and 2, synaptojanin, AP180, epsin and eps15, and AP-2 are phosphorylated. Although it is clear that phosphorylation plays an important role in clathrin-mediated internalization, a more detailed understanding of the endocytic regulatory mechanisms will require the identification of the respective kinases that target endocytic components. Multiple kinases of clathrin-coated vesicles have been defined, for example AAK1 phosphorylates the $\mu 2$ subunit of AP-2 [84], Src kinase phosphorylates clathrin [78], and the $\beta 2$-subunit of AP-2 [105]. Previous observations suggest that the poly-L-lysine dependent phosphorylation of AP-2 prevents its recruitment to clathrin cages [74]. Thus, it is reasonable to believe that 
phosphorylation may regulate the ability of AP-2 to interact with other endocytic proteins, such as $\beta$-arrestin. However, we can not exclude the fact that phosphorylation may also influence AP-2 localization. Previous studies have established that $\beta 2$-adaptin is phosphorylated in vivo by a staurosporinesensitive kinase whose function is balanced by the constitutive activity of protein phosphatase 2A (PP2A) [142]. They also observed that treatment of cells with agents that block PP2A function perturb AP-2 localization at the plasma membrane and disrupt transferrin internalization. Thus, as suggested by Slepnev et al. [127], it is possible that one potential mechanism to regulate the cycles of coat protein assembly and disassembly is reversible phosphorylation.

In conclusion, phosphorylation appears to be an important mechanism by which GPCRs regulate their own internalization. We currently have only a few pieces of the puzzle available. The identity of many kinases and phosphatases, their location, and the timing of their action remain to be determined. In the future, it will be interesting to investigate the molecular consequences of protein phosphorylation, how kinases are regulated, and where and how phosphorylation versus dephosphorylation occurs. These issues are crucial to our understanding for the regulation of receptor internalization through clathrin-coated vesicles

\section{References}

[1] S. M. DeWire, S. Ahn, R. J. Lefkowitz, and S. K. Shenoy, “ $\beta$ arrestins and cell signaling," Annual Review of Physiology, vol. 69, pp. 483-510, 2007.

[2] S. K. Shenoy and R. J. Lefkowitz, "Seven-transmembrane receptor signaling through beta-arrestin," Science, vol. 2005, no. 308, pp. 512-517, 2005.

[3] R. J. Lefkowitz, K. Rajagopal, and E. J. Whalen, "New roles for beta-arrestins in cell signaling: not just for seventransmembrane receptors," Molecular Cell, vol. 24, no. 5, pp. 643-652, 2006.

[4] S. S. G. Ferguson, "Phosphorylation-independent attenuation of GPCR signalling," Trends in Pharmacological Sciences, vol. 28, no. 4, pp. 173-179, 2007.

[5] P. Samama, S. Cotecchia, T. Costa, and R. J. Lefkowitz, "A mutation-induced activated state of the $\beta$-adrenergic receptor. Extending the ternary complex model," Journal of Biological Chemistry, vol. 268, no. 7, pp. 4625-4636, 1993.

[6] H. Damke, T. Baba, D. E. Warnock, and S. L. Schmid, "Induction of mutant dynamin specifically blocks endocytic coated vesicle formation," Journal of Cell Biology, vol. 127, no. 4, pp. 915-934, 1994.

[7] W. P. Hausdorff, M. G. Caron, and R. J. Lefkowitz, “Turning off the signal: desensitization of $\beta$-adrenergic receptor function," FASEB Journal, vol. 4, no. 11, pp. 2881-2889, 1990.

[8] D. R. Sibley, R. H. Strasser, and J. L. Benovic, "Phosphorylation/dephosphorylation of the $\beta$-adrenergic receptor regulates its functional coupling to adenylate cyclase and subcellular distribution," Proceedings of the National Academy of Sciences of the United States of America, vol. 83, no. 24, pp. 9408-9412, 1986.

[9] C. Ribas, P. Penela, C. Murga et al., "The G protein-coupled receptor kinase (GRK) interactome: role of GRKs in GPCR regulation and signaling," Biochimica et Biophysica Acta, vol. 1768, no. 4, pp. 913-922, 2007.
[10] A. Mestek, J. H. Hurley, L. S. Bye et al., "The human $\mu$ opioid receptor: modulation of functional desensitization by calcium/calmodulin-dependent protein kinase and protein kinase C," Journal of Neuroscience, vol. 15, no. 3, pp. 23962406, 1995.

[11] D. Diviani, A. L. Lattion, and S. Cotecchia, "Characterization of the phosphorylation sites involved in G protein-coupled receptor kinase- and protein kinase C-mediated desensitization of the $\alpha(1 \mathrm{~B})$-adrenergic receptor," Journal of Biological Chemistry, vol. 272, no. 45, pp. 28712-28719, 1997.

[12] Y. Qiu, P. Y. Law, and H. H. Loh, “ $\mu$-opioid receptor desensitization: role of receptor phosphorylation, internalization, and resensitization," Journal of Biological Chemistry, vol. 278, no. 38, pp. 36733-36739, 2003.

[13] J. L. Benovic, A. DeBlasi, W. C. Stone, M. G. Caron, and R. J. Lefkowitz, " $\beta$-Adrenergic receptor kinase: primary structure delineates a multigene family," Science, vol. 246, no. 4927, pp. 235-240, 1989.

[14] N. J. Freedman, S. B. Liggett, D. E. Drachman, G. Pei, M. G. Caron, and R. J. Lefkowitz, "Phosphorylation and desensitization of the human $\beta$-adrenergic receptor. Involvement of $\mathrm{G}$ protein-coupled receptor kinases and cAMP-dependent protein kinase," Journal of Biological Chemistry, vol. 270, no. 30, pp. 17953-17961, 1995.

[15] K. L. Pierce, R. T. Premont, and R. J. Lefkowitz, "Seventransmembrane receptors," Nature Reviews Molecular Cell Biology, vol. 3, no. 9, pp. 639-650, 2002.

[16] Y. Daaka, L. M. Luttrell, and R. J. Lefkowitz, "Switching of the coupling of the $\beta$-adrenergic receptor to different $g$ proteins by protein kinase A," Nature, vol. 390, no. 6655, pp. 88-91, 1997.

[17] O. A. Lawler, S. M. Miggin, and B. T. Kinsella, "Protein kinase A-mediated phosphorylation of serine 357 of the mouse prostacyclin receptor regulates its coupling to $G(s)$-, to $G(i)$-, and to G(q)-coupled effector signaling," Journal of Biological Chemistry, vol. 276, no. 36, pp. 33596-33607, 2001.

[18] B. P. Fairfax, J. A. Pitcher, M. G. H. Scott et al., "Phosphorylation and chronic agonist treatment atypically modulate GABAB receptor cell surface stability," Journal of Biological Chemistry, vol. 279, no. 13, pp. 12565-12573, 2004.

[19] S. M. Pontier, N. Lahaie, R. Ginham et al., "Coordinated action of NSF and PKC regulates GABA receptor signaling efficacy," EMBO Journal, vol. 25, no. 12, pp. 2698-2709, 2006.

[20] N. Kuramoto, M. E. Wilkins, B. P. Fairfax et al., "Phosphodependent functional modulation of $\mathrm{GABA}(\mathrm{B})$ receptors by the metabolic sensor AMP-dependent protein kinase," Neuron, vol. 53, no. 2, pp. 233-247, 2007.

[21] U. Wilden and H. Kühn, "Light-dependent phosphorylation of rhodopsin: number of phosphorylation sites," Biochemistry, vol. 21, no. 12, pp. 3014-3022, 1982.

[22] J. M. Stadel, P. Nambi, R. G. Shorr, D. F. Sawyer, M. G. Caron, and R. J. Lefkowitz, "Catecholamine-induced desensitization of turkey erythrocyte adenylate cyclase is associated with phosphorylation of the beta-adrenergic receptor," Proceedings of the National Academy of Sciences of the United States of America, vol. 80, pp. 3173-3177, 1983.

[23] H. Shichi and R. L. Somers, "Light-dependent phosphorylation of rhodopsin. Purification and properties of rhodopsin kinase," Journal of Biological Chemistry, vol. 253, no. 19, pp. 7040-7046, 1978.

[24] J. L. Benovic, R. H. Strasser, M. G. Caron, and R. J. Lefkowitz, " $\beta$-adrenergic receptor kinase: identification of 
a novel protein kinase that phosphorylates the agonistoccupied form of the receptor," Proceedings of the National Academy of Sciences of the United States of America, vol. 83, no. 9, pp. 2797-2801, 1986.

[25] W. P. Hausdorff, M. J. Lohse, M. Bouvier, S. B. Liggett, M. G. Caron, and R. J. Lefkowitz, "Two kinases mediate agonist-dependent phosphorylation and desensitization of the beta 2-adrenergic receptor," Symposia of the Society for Experimental Biology, vol. 44, pp. 225-240, 1990.

[26] R. T. Premont, J. Inglese, and R. J. Lefkowitz, "Protein kinases that phosphorylate activated G protein-coupled receptors," FASEB Journal, vol. 9, no. 2, pp. 175-182, 1995.

[27] C. Y. Chen, S. B. Dion, C. M. Kim, and J. L. Benovic, " $\beta$-adrenergic receptor kinase. Agonist-dependent receptor binding promotes kinase activation," Journal of Biological Chemistry, vol. 268, no. 11, pp. 7825-7831, 1993.

[28] R. Sterne-Marr and J. L. Benovic, "Regulation of G proteincoupled receptors by receptor kinases and arrestins," Vitamins and Hormones, vol. 51, pp. 193-234, 1995.

[29] D. T. Lodowski, J. A. Pitcher, W. D. Capel, R. J. Lefkowitz, and J. J.G. Tesmer, "Keeping G proteins at bay: a complex between G protein-coupled receptor kinase 2 and G $\beta \gamma$," Science, vol. 300, no. 5623, pp. 1256-1262, 2003.

[30] R. T. Premont, A. D. Macrae, R. H. Stoffel et al., "Characterization of the $\mathrm{G}$ protein-coupled receptor kinase GRK4: identification of four splice vaeiants," Journal of Biological Chemistry, vol. 271, no. 11, pp. 6403-6410, 1996.

[31] J. A. Pitcher, N. J. Freedman, and R. J. Lefkowitz, "G proteincoupled receptor kinases," Annual Review of Biochemistry, vol. 67, pp. 653-692, 1998.

[32] J. M. Willets, R. A. J. Challiss, and S. R. Nahorski, "Nonvisual GRKs: are we seeing the whole picture?" Trends in Pharmacological Sciences, vol. 24, no. 12, pp. 626-633, 2003.

[33] J. Kim, S. Ahn, X. R. Ren et al., "Functional antagonism of different $G$ protein-coupled receptor kinases for $\beta$-arrestinmediated angiotensin II receptor signaling," Proceedings of the National Academy of Sciences of the United States of America, vol. 102, no. 5, pp. 1442-1447, 2005.

[34] X. R. Ren, E. Reiter, S. Ahn, J. Kim, W. Chen, and R. J. Lefkowitz, "Different G protein-coupled receptor kinases govern $\mathrm{G}$ protein and $\beta$-arrestin-mediated signaling of V2 vasopressin receptor," Proceedings of the National Academy of Sciences of the United States of America, vol. 102, no. 5, pp. 1448-1453, 2005.

[35] J. A. Pitcher, J. J. G. Tesmer, J. L. R. Freeman, W. D. Capel, W. C. Stone, and R. J. Lefkowitz, "Feedback inhibition of G protein-coupled receptor kinase 2 (GRK2) activity by extracellular signal-regulated kinases," Journal of Biological Chemistry, vol. 274, no. 49, pp. 34531-34534, 1999.

[36] R. Winstel, S. Freund, C. Krasel, E. Hoppe, and M. J. Lohse, "Protein kinase cross-talk: membrane targeting of the $\beta$ adrenergic receptor kinase by protein kinase C," Proceedings of the National Academy of Sciences of the United States of America, vol. 93, no. 5, pp. 2105-2109, 1996.

[37] M. Cong, S. J. Perry, F. T. Lin et al., "Regulation of membrane targeting of the G protein-coupled receptor kinase 2 by protein kinase A and its anchoring protein AKAP79," Journal of Biological Chemistry, vol. 276, no. 18, pp. 15192-15199, 2001.

[38] T. T. Chuang, H. LeVine III, and A. De Blasi, "Phosphorylation and activation of $\beta$-adrenergic receptor kinase by protein kinase C," Journal of Biological Chemistry, vol. 270, no. 31, pp. 18660-18665, 1995.
[39] T. T. Chuang, L. Paolucci, and A. De Blasi, "Inhibition of $G$ protein-coupled receptor kinase subtypes by Ca2+/calmodulin," Journal of Biological Chemistry, vol. 271, no. 45, pp. 28691-28696, 1996.

[40] P. Penela, A. Elorza, S. Sarnago, and F. Mayor, " $\beta$-arrestinand c-Src-dependent degradation of G-protein-coupled receptor kinase 2," EMBO Journal, vol. 20, no. 18, pp. 51295138, 2001.

[41] A. Elorza, P. Penela, S. Sarnago, and F. Mayor, "MAPKdependent degradation of $G$ protein-coupled receptor kinase 2," Journal of Biological Chemistry, vol. 278, no. 31, pp. 29164-29173, 2003.

[42] U. Wilden, S. W. Hall, and H. Kuhn, "Phosphodiesterase activation by photoexcited rhodopsin is quenched when rhodopsin is phosphorylated and binds the intrinsic $48-\mathrm{kDa}$ protein of rod outer segments," Proceedings of the National Academy of Sciences of the United States of America, vol. 83, no. 5, pp. 1174-1178, 1986.

[43] R. Zuckerman and J. E. Cheasty, "A $48 \mathrm{kDa}$ protein arrests cGMP phosphodiesterase activation in retinal rod disk membranes," FEBS Letters, vol. 207, no. 1, pp. 35-41, 1986.

[44] R. H. Oakleyt, C. M. Jewell, M. R. Yudt, D. M. Bofetiado, and J. A. Cidlowski, "The dominant negative activity of the human glucocorticoid receptor $\beta$ isoform. Specificity and mechanisms of action," Journal of Biological Chemistry, vol. 274, no. 39, pp. 27857-27866, 1999.

[45] H. Qian, L. Pipolo, and W. G. Thomas, "Association of $\beta$-arrestin 1 with the type $1 \mathrm{~A}$ angiotensin II receptor involves phosphorylation of the receptor carboxyl terminus and correlates with receptor internalization," Molecular Endocrinology, vol. 15, no. 10, pp. 1706-1719, 2001.

[46] R. Pals-Rylaarsdam, V. V. Gurevich, K. B. Lee, J. A. Ptasienski, J. L. Benovic, and M. M. Hosey, "Internalization of the $\mathrm{m} 2$ muscarinic acetylcholine receptor. Arrestin-independent and -dependent pathways," Journal of Biological Chemistry, vol. 272, no. 38, pp. 23682-23689, 1997.

[47] S. A. Vishnivetskiy, C. L. Paz, C. Schubert, J. A. Hirsch, P. B. Sigler, and V. V. Gurevich, "How does arrestin respond to the phosphorylated state of rhodopsin?" Journal of Biological Chemistry, vol. 274, no. 17, pp. 11451-11454, 1999.

[48] R. H. Oakley, S. A. Laporte, J. A. Holt, L. S. Barak, and M. G. Caron, "Association of $\beta$-arrestin with $\mathrm{G}$ protein-coupled receptors during clathrin-mediated endocytosis dictates the profile of receptor resensitization," Journal of Biological Chemistry, vol. 274, no. 45, pp. 32248-32257, 1999.

[49] M. J. Lohse, J. L. Benovic, J. Codina, M. G. Cargon, and R. J. Lefkowitz, " $\beta$-arrestin: a protein that regulates $\beta$-adrenergic receptor function," Science, vol. 248, no. 4962, pp. 1547-1550, 1990.

[50] V. V. Gurevich, S. B. Dion, J. J. Onorato et al., "Arrestin interactions with $G$ protein-coupled receptors. Direct binding studies of wild type and mutant arrestins with rhodopsin, $\beta$-adrenergic, and $\mathrm{m} 2$ muscarinic cholinergic receptors," Journal of Biological Chemistry, vol. 270, no. 2, pp. 720-731, 1995.

[51] N. Malecz, T. Bambino, M. Bencsik, and R. A. Nissenson, "Identification of phosphorylation sites in the G proteincoupled receptor for parathyroid hormone. Receptor phosphorylation is not required for agonist-induced internalization," Molecular Endocrinology, vol. 12, no. 12, pp. 18461856, 1998.

[52] M. D. Richardson, A. M. Balius, K. Yamaguchi, E. R. Freilich, L. S. Barak, and M. M. Kwatra, "Human substance P receptor lacking the $\mathrm{C}$-terminal domain remains competent 
to desensitize and internalize," Journal of Neurochemistry, vol. 84, no. 4, pp. 854-863, 2003.

[53] S. R. Murray, C. J. Evans, and M. Von Zastrow, "Phosphorylation is not required for dynamin-dependent endocytosis of a truncated mutant opioid receptor," Journal of Biological Chemistry, vol. 273, no. 39, pp. 24987-24991, 1998.

[54] V. R. Jala, W. H. Shao, and B. Haribabu, "Phosphorylationindependent $\beta$-arrestin translocation and internalization of leukotriene B receptors," Journal of Biological Chemistry, vol. 280, no. 6, pp. 4880-4887, 2005.

[55] O. J. Kim, B. R. Gardner, D. B. Williams et al., "The role of phosphorylation in $\mathrm{D}$ dopamine receptor desensitization: evidence for a novel mechanism of arrestin association," Journal of Biological Chemistry, vol. 279, no. 9, pp. 79998010, 2004.

[56] I. Torrecilla, E. J. Spragg, B. Poulin et al., "Phosphorylation and regulation of a $\mathrm{G}$ protein-coupled receptor by protein kinase CK2," Journal of Cell Biology, vol. 177, no. 1, pp. 127137, 2007.

[57] A. C. Hanyaloglu, M. Vrecl, K. M. Kroeger et al., "Casein kinase II sites in the intracellular C-terminal domain of the thyrotropin-releasing hormone receptor and chimeric gonadotropin-releasing hormone receptors contribute to beta-arrestin-dependent internalization," Journal of Biological Chemistry, vol. 276, no. 21, pp. 18066-18074, 2001.

[58] R. Gaudreau, C. L. Gouill, M. H. Venne, J. Stankova, and M. Rola-Pleszczynski, "Threonine 308 within a putative casein kinase 2 site of the cytoplasmic tail of leukotriene $\mathrm{B}$ receptor (BLT1) is crucial for ligand-induced, G-proteincoupled receptor-specific kinase 6-mediated desensitization," Journal of Biological Chemistry, vol. 277, no. 35, pp. 3156731576, 2002.

[59] H. Rebholz, A. Nishi, S. Liebscher, A. C. Nairn, M. Flajolet, and P. Greengard, "CK2 negatively regulates $\mathrm{G} \alpha$ signaling," Proceedings of the National Academy of Sciences of the United States of America, vol. 106, no. 33, pp. 14096-14101, 2009.

[60] F. T. Lin, K. M. Krueger, H. E. Kendall et al., "Clathrinmediated endocytosis of the $\beta$-adrenergic receptor is regulated by phosphorylation/dephosphorylation of $\beta$-arrestin1," Journal of Biological Chemistry, vol. 272, no. 49, pp. 3105131057, 1997.

[61] F. T. Lin, W. E. Miller, L. M. Luttrell, and R. J. Lefkowitz, "Feedback regulation of $\beta$-arrestin1 function by extracellular signal-regulated kinases," Journal of Biological Chemistry, vol. 274, no. 23, pp. 15971-15974, 1999.

[62] L. M. Luttrell, S. S.G. Ferguson, Y. Daaka et al., " $\beta$-arrestindependent formation of $\beta 2$ adrenergic receptor-src protein kinase complexes," Science, vol. 283, no. 5402, pp. 655-661, 1999.

[63] G. Barthet, G. Carrat, E. Cassier et al., "Beta-arrestin1 phosphorylation by GRK5 regulates $\mathrm{G}$ protein-independent 5-HT 4 receptor signalling," EMBO Journal, vol. 28, no. 18, pp. 2706-2718, 2009.

[64] Y. M. Kim, L. S. Barak, M. G. Caron, and J. L. Benovic, "Regulation of arrestin-3 phosphorylation by casein kinase II," Journal of Biological Chemistry, vol. 277, no. 19, pp. 16837-16846, 2002.

[65] F. T. Lin, W. Chen, S. Shenoy, M. Cong, S. T. Exum, and R. J. Lefkowitz, "Phosphorylation of $\beta$-arrestin2 regulates its function in internalization of $\beta$-adrenergic receptors," Biochemistry, vol. 41, no. 34, pp. 10692-10699, 2002.

[66] E. S. Kahn and H. Matsumoto, "Calcium/calmodulindependent kinase II phosphorylates Drosophila visual arrestin," Journal of Neurochemistry, vol. 68, no. 1, pp. 169175, 1997.

[67] H. Matsumoto, B. T. Kurien, Y. Takagi et al., "Phosrestin I undergoes the earliest light-induced phosphorylation by a calcium/calmodulin-dependent protein kinase in Drosophila photoreceptors," Neuron, vol. 12, no. 5, pp. 997-1010, 1994.

[68] P. G. Alloway and P. J. Dolph, "A role for the lightdependent phosphorylation of visual arrestin," Proceedings of the National Academy of Sciences of the United States of America, vol. 96, no. 11, pp. 6072-6077, 1999.

[69] T. Byk, M. Bar-Yaacov, Y. N. Doza, B. Minke, and Z. Selinger, "Regulatory arrestin cycle secures the fidelity and maintenance of the fly photoreceptor cell," Proceedings of the National Academy of Sciences of the United States of America, vol. 90, no. 5, pp. 1907-1911, 1993.

[70] E. A. Richard and J. E. Lisman, "Rhodopsin inactivation is a modulated process in Limulus photoreceptors," Nature, vol. 356, no. 6367, pp. 336-338, 1992.

[71] K. Scott and C. Zuker, "Lights out: deactivation of the phototransduction cascade," Trends in Biochemical Sciences, vol. 22, no. 9, pp. 350-354, 1997.

[72] S. Marion, G. B. Fralish, S. Laporte, M. G. Caron, and L. S. Barak, "N-terminal tyrosine modulation of the endocytic adaptor function of the $\beta$-arrestins," Journal of Biological Chemistry, vol. 282, no. 26, pp. 18937-18944, 2007.

[73] K. Xiao, J. Sun, J. Kim et al., "Global phosphorylation analysis of $\beta$-arrestin-mediated signaling downstream of a seven transmembrane receptor (7TMR)," Proceedings of the National Academy of Sciences of the United States of America, vol. 107, no. 34, pp. 15299-15304, 2010.

[74] A. Wilde and F. M. Brodsky, "In vivo phosphorylation of adaptors regulates their interaction with clathrin," Journal of Cell Biology, vol. 135, no. 3, pp. 635-645, 1996.

[75] D. Bar-Zvi and D. Branton, "Clathrin-coated vesicles contain two protein kinase activities. Phosphorylation of clathrin $\beta$-light chain by casein kinase II," Journal of Biological Chemistry, vol. 261, no. 21, pp. 9614-9621, 1986.

[76] D. Bar-Zvi, S. T. Mosley, and D. Branton, "In vivo phosphorylation of clathrin-coated vesicle proteins from rat reticulocytes," Journal of Biological Chemistry, vol. 263, no. 9, pp. 4408-4415, 1988.

[77] V. Georgieva-Hanson, W. J. Schook, and S. Puszkin, "Brain coated vesicle destabilization and phosphorylation of coat proteins," Journal of Neurochemistry, vol. 50, no. 1, pp. 307315, 1988.

[78] A. Wilde, E. C. Beattie, L. Lem et al., "EGF receptor signaling stimulates SRC kinase phosphorylation of clathrin, influencing clathrin redistribution and EGF uptake," Cell, vol. 96, no. 5, pp. 677-687, 1999.

[79] L. F. Cotlin, M. A. Siddiqui, F. Simpson, and J. F. Collawn, "Casein kinase II activity is required for transferrin receptor endocytosis," Journal of Biological Chemistry, vol. 274, no. 43, pp. 30550-30556, 1999.

[80] W. Shih, A. Gallusser, and T. Kirchhausen, "A clathrinbinding site in the hinge of the $\beta 2$ chain of mammalian AP-2 complexes," Journal of Biological Chemistry, vol. 270, no. 52, pp. 31083-31090, 1995.

[81] L. M. Traub, "Sorting it out: AP-2 and alternate clathrin adaptors in endocytic cargo selection," Journal of Cell Biology, vol. 163, no. 2, pp. 203-208, 2003.

[82] E. Smythe, "Regulating the clathrin-coated vesicle cycle by AP2 subunit phosphorylation," Trends in Cell Biology, vol. 12, no. 8, pp. 352-354, 2002. 
[83] D. Ricotta, S. D. Conner, S. L. Schmid, K. Von Figura, and S. Höning, "Phosphorylation of the AP2 $\mu$ subunit by AAK1 mediates high affinity binding to membrane protein sorting signals," Journal of Cell Biology, vol. 156, no. 5, pp. 791-795, 2002.

[84] S. D. Conner and S. L. Schmid, "Identification of an adaptorassociated kinase, AAK1, as a regulator of clathrin-mediated endocytosis," Journal of Cell Biology, vol. 156, no. 5, pp. 921929, 2002.

[85] V. I. Korolchuk and G. Banting, "CK2 and GAK/auxilin2 are major protein kinases in clathrin-coated vesicles," Traffic, vol. 3, no. 6, pp. 428-439, 2002.

[86] A. Umeda, A. Meyerholz, and E. Ungewickell, "Identification of the universal cofactor (auxilin 2) in clathrin coat dissociation," European Journal of Cell Biology, vol. 79, no. 5, pp. 336-342, 2000.

[87] T. Greener, X. Zhao, H. Nojima, E. Eisenberg, and L. E. Greene, "Role of cyclin G-associated kinase in uncoating clathrin-coated vesicles from non-neuronal cells," Journal of Biological Chemistry, vol. 275, no. 2, pp. 1365-1370, 2000.

[88] S. R. Flute, E. B. Porro, V. I. Slepnev, G. C. Ochoa, L. H. Tsai, and P. De Camilli, "Amphiphysin 1 binds the cyclindependent kinase (cdk) 5 regulatory subunit p35 and is phosphorylated by cdk5 and cdc2," Journal of Biological Chemistry, vol. 276, no. 11, pp. 8104-8110, 2001.

[89] D. W. Lee, X. Zhao, Y. I. Yim, E. Eisenberg, and L. E. Greene, "Essential role of cyclin-G-associated kinase (auxilin-2) in developing and mature mice," Molecular Biology of the Cell, vol. 19, no. 7, pp. 2766-2776, 2008.

[90] O. Olusanya, P. D. Andrews, J. R. Swedlow, and E. Smythe, "Phosphorylation of threonine 156 of the $\mu 2$ subunit of the AP2 complex is essential for endocytosis in vitro and in vivo," Current Biology, vol. 11, no. 11, pp. 896-900, 2001.

[91] S. D. Conner and S. L. Schmid, "Differential requirements for AP-2 in clathrin-mediated endocytosis," Journal of Cell Biology, vol. 162, no. 5, pp. 773-779, 2003.

[92] A. M. Motley, N. Berg, M. J. Taylor et al., "Functional analysis of AP- $2 \alpha$ and $\mu 2$ subunits," Molecular Biology of the Cell, vol. 17, no. 12, pp. 5298-5308, 2006.

[93] A. Fingerhut, K. Von Figura, and S. Höning, "Binding of AP2 to sorting signals is modulated by AP2 phosphorylation," Journal of Biological Chemistry, vol. 276, no. 8, pp. 54765482, 2001.

[94] S. Semerdjieva, B. Shortt, E. Maxwell et al., "Coordinated regulation of AP2 uncoating from clathrin-coated vesicles by rab5 and hRME-6," Journal of Cell Biology, vol. 183, no. 3, pp. 499-511, 2008.

[95] L. M. Luttrell, B. E. Hawes, T. Van Biesen, D. K. Luttrell, T. J. Lansing, and R. J. Lefkowitz, "Role of c-Src tyrosine kinase in $G$ protein-coupled receptor- and $G \beta \gamma$ subunit-mediated activation of mitogen-activated protein kinases," Journal of Biological Chemistry, vol. 271, no. 32, pp. 19443-19450, 1996.

[96] Y. H. Chen, J. Pouyssegur, S. A. Courtneidge, and E. Van Obberghen-Schilling, "Activation of Src family kinase activity by the G protein-coupled thrombin receptor in growthresponsive fibroblasts," Journal of Biological Chemistry, vol. 269, no. 44, pp. 27372-27377, 1994.

[97] M. S. Simonson and W. H. Herman, "Protein kinase C and protein tyrosine kinase activity contribute to mitogenic signaling by endothelin-1. Cross-talk between G proteincoupled receptors and pp60(c-src)," Journal of Biological Chemistry, vol. 268, no. 13, pp. 9347-9357, 1993.

[98] B. Schieffer, W. G. Paxton, Q. Chai, M. B. Marrero, and K. E. Bernstein, "Angiotensin II controls p21 activity via pp60,"
Journal of Biological Chemistry, vol. 271, no. 17, pp. 1032910333, 1996.

[99] A. Ptasznik, A. Traynor-Kaplan, and G. M. Bokoch, "G protein-coupled chemoattractant receptors regulate Lyn tyrosine kinase-Shc adapter protein signaling complexes," Journal of Biological Chemistry, vol. 270, no. 34, pp. 1996919973, 1995.

[100] A. Seungkirl, S. Maudsley, L. M. Luttrell, R. J. Lefkowitz, and Y. Daaka, "Src-mediated tyrosine phosphorylation of dynamin is required for $\beta$-adrenergic receptor internalization and mitogen-activated protein kinase signaling," Journal of Biological Chemistry, vol. 274, no. 3, pp. 1185-1188, 1999.

[101] D. Fessart, M. Simaan, and S. A. Laporte, "c-Src regulates clathrin adapter protein 2 interaction with $\beta$-arrestin and the angiotensin II type 1 receptor during clathrin-mediated internalization," Molecular Endocrinology, vol. 19, no. 2, pp. 491-503, 2005.

[102] M. T. Brown and J. A. Cooper, "Regulation, substrates and functions of src," Biochimica et Biophysica Acta, vol. 1287, no. 2-3, pp. 121-149, 1996.

[103] J. Huang, Y. Sun, and X. Y. Huang, "Distinct roles for Src tyrosine kinase in $\beta$-adrenergic receptor signaling to MAPK and in receptor internalization," Journal of Biological Chemistry, vol. 279, no. 20, pp. 21637-21642, 2004.

[104] W. E. Miller, S. Maudsley, S. Ahn, K. D. Khan, L. M. Luttrell, and R. J. Lefkowitz, " $\beta$-arrestin1 interacts with the catalytic domain of the tyrosine kinase c-SRC. Role of $\beta$-arrestin1dependent targeting of c-SRC in receptor endocytosis," Journal of Biological Chemistry, vol. 275, no. 15, pp. 1131211319, 2000.

[105] D. Fessart, M. Simaan, B. Zimmerman et al., "Src-dependent phosphorylation of beta2-adaptin dissociates the betaarrestin-AP-2 complex," Journal of Cell Science, vol. 120, pp. 1723-1732, 2007.

[106] B. Zimmerman, M. Simaan, M. H. Lee, L. M. Luttrell, and S. A. Laporte, "c-Src-mediated phosphorylation of AP-2 reveals a general mechanism for receptors internalizing through the clathrin pathway," Cellular Signalling, vol. 21, no. 1, pp. 103110, 2009.

[107] O. B. Goodman Jr., J. G. Krupnick, F. Santini et al., “ $\beta$ arrestin acts as a clathrin adaptor in endocytosis of the $\beta 2$ adrenergic receptor," Nature, vol. 383, no. 6599, pp. 447-450, 1996.

[108] J. Zhang, L. S. Barak, K. E. Winkler, M. G. Caron, and S. S.G. Ferguson, "A central role for $\beta$-arrestins and clathrincoated vesicle-mediated endocytosis in $\beta 2$-adrenergic receptor resensitization. Differential regulation of receptor resensitization in two distinct cell types," Journal of Biological Chemistry, vol. 272, no. 43, pp. 27005-27014, 1997.

[109] M. G. H. Scott, A. Benmerah, O. Muntaner, and S. Marullo, "Recruitment of activated G protein-coupled receptors to pre-existing clathrin-coated pits in living cells," Journal of Biological Chemistry, vol. 277, no. 5, pp. 3552-3559, 2002.

[110] F. Santini, I. Gaidarov, and J. H. Keen, "G protein-coupled receptor/arrestin3 modulation of the endocytic machinery," Journal of Cell Biology, vol. 156, no. 4, pp. 665-676, 2002.

[111] Y. Werbonat, N. Kleutges, K. H. Jakobs, and C. J. Van Koppen, "Essential role of dynamin in internalization of M muscarinic acetylcholine and angiotensin AT(1A) receptors," Journal of Biological Chemistry, vol. 275, no. 29, pp. 21969-21974, 2000.

[112] H. Cao, J. Chen, E. W. Krueger, and M. A. McNiven, "Srcmediated phosphorylation of dynamin and cortactin regulates the "constitutive" endocytosis of transferrin," Molecular and Cellular Biology, vol. 30, no. 3, pp. 781-792, 2010. 
[113] S. Ahn, J. Kim, C. L. Lucaveche et al., "Src-dependent tyrosine phosphorylation regulates dynamin self-assembly and ligand-induced endocytosis of the epidermal growth factor receptor," Journal of Biological Chemistry, vol. 277, no. 29, pp. 26642-26651, 2002.

[114] P. J. Robinson, "Differential stimulation of protein kinase C activity by phorbol ester or calcium/phosphatidylserine in vitro and in intact synaptosomes," Journal of Biological Chemistry, vol. 267, no. 30, pp. 21637-21644, 1992.

[115] P. J. Robinson, J. M. Sontag, J. P. Liu et al., "Dynamin GTPase regulated by protein kinase $C$ phosphorylation in nerve terminals," Nature, vol. 365, no. 6442, pp. 163-166, 1993.

[116] J. P. Liu, K. A. Powell, T. C. Sudhof, and P. J. Robinson, "Dynamin I is a Ca-sensitive phospholipid-binding protein with very high affinity for protein kinase C," Journal of Biological Chemistry, vol. 269, no. 33, pp. 21043-21050, 1994.

[117] J. M. Sontag, E. M. Fykse, Y. Ushkaryov, J. P. Liu, P. J. Robinson, and T. C. Sudhof, "Differential expression and regulation of multiple dynamins," Journal of Biological Chemistry, vol. 269, no. 6, pp. 4547-4554, 1994.

[118] J. P. Liu, A. T. R. Sim, and P. J. Robinson, "Calcineurin inhibition of dynamin I GTPase activity coupled to nerve terminal depolarization," Science, vol. 265, no. 5174, pp. 970 973, 1994.

[119] R. A. Nichols, G. R. Suplick, and J. M. Brown, "Calcineurinmediated protein dephosphorylation in brain nerve terminals regulates the release of glutamate," Journal of Biological Chemistry, vol. 269, no. 38, pp. 23817-23823, 1994.

[120] R. Bauerfeind, K. Takei, and P. De Camilli, "Amphiphysin I is associated with coated endocytic intermediates and undergoes stimulation-dependent dephosphorylation in nerve terminals," Journal of Biological Chemistry, vol. 272, no. 49, pp. 30984-30992, 1997.

[121] B. Marks and H. T. McMahon, "Calcium triggers calcineurindependent synaptic vesicle recycling in mammalian nerve terminals," Current Biology, vol. 8, no. 13, pp. 740-749, 1998.

[122] P. J. Robinson, J. P. Liu, K. A. Powell, E. M. Fykse, and T. C. Sudhof, "Phosphorylation of dynamin I and synaptic-vesicle recycling," Trends in Neurosciences, vol. 17, no. 8, pp. 348353, 1994.

[123] M. A. Cousin, T. C. Tan, and P. J. Robinson, "Protein phosphorylation is required for endocytosis in nerve terminals: potential role for the dephosphins dynamin I and synaptojanin, but not AP180 or amphiphysin," Journal of Neurochemistry, vol. 76, no. 1, pp. 105-116, 2001.

[124] R. Dhavan and L. H. Tsai, "A decade of CDK5," Nature Reviews Molecular Cell Biology, vol. 2, no. 10, pp. 749-759, 2001.

[125] K. Tomizawa, S. Sunada, Y. F. Lu et al., "Cophosphorylation of amphiphysin I and dynamin I by Cdk 5 regulates clathrinmediated endocytosis of synaptic vesicles," Journal of Cell Biology, vol. 163, no. 4, pp. 813-824, 2003.

[126] P. S. McPherson, E. P. Garcia, V. I. Slepnev et al., "A presynaptic inositol-5-phosphatase," Nature, vol. 379, no. 6563, pp. 353-357, 1996.

[127] V. I. Slepnev, G. C. Ochoa, M. H. Butler, D. Grabs, and P. De Camilli, "Role of phosphorylation in regulation of the assembly of endocytic coat complexes," Science, vol. 281, no. 5378, pp. 821-824, 1998.

[128] P. Wigge, K. Köhler, Y. Vallis et al., "Amphiphysin heterodimers: potential role in clathrin-mediated endocytosis," Molecular Biology of the Cell, vol. 8, no. 10, pp. 2003-2015, 1997.
[129] C. David, P. S. McPherson, O. Mundigl, and P. De Camilli, "A role of amphiphysin in synaptic vesicle endocytosis suggested by its binding to dynamin in nerve terminals," Proceedings of the National Academy of Sciences of the United States of America, vol. 93, no. 1, pp. 331-335, 1996.

[130] D. Grabs, V. I. Slepnev, Z. Songyang et al., "The SH3 domain of amphiphysin binds the proline-rich domain of dynamin at a single site that defines a new $\mathrm{SH} 3$ binding consensus sequence," Journal of Biological Chemistry, vol. 272, no. 20, pp. 13419-13425, 1997.

[131] O. Shupliakov, P. Löw, D. Grabs et al., "Synaptic vesicle endocytosis impaired by disruption of dynamin-SH3 domain interactions," Science, vol. 276, no. 5310, pp. 259-263, 1997.

[132] L. H. Wang, T. C. Sudhof, and R. G. W. Anderson, "The appendage domain of $\alpha$-adaptin is a high affinity binding site for dynamin," Journal of Biological Chemistry, vol. 270, no. 17, pp. 10079-10083, 1995.

[133] J. A. Bibb, J. Chen, J. R. Taylor et al., "Effects of chronic exposure to cocaine are regulated by the neuronal protein Cdk5," Nature, vol. 410, no. 6826, pp. 376-380, 2001.

[134] K. Tomizawa, J. Ohta, M. Matsushita et al., "Cdk5/p35 regulates neurotransmitter release through phosphorylation and downregulation of P/Q-type voltage-dependent calcium channel activity," Journal of Neuroscience, vol. 22, no. 7, pp. 2590-2597, 2002.

[135] W. H. Shang, Y. Adachi, A. Nakamura, T. Copeland, S. R. Kim, and T. Kamata, "Regulation of amphiphysin 1 by mitogen-activated protein kinase: its significance in nerve growth factor receptor-mediated endocytosis," Journal of Biological Chemistry, vol. 279, no. 39, pp. 40890-40896, 2004.

[136] M. Döring, A. Loos, N. Schrader, B. Pfander, and R. Bauerfeind, "Nerve growth factor-induced phosphorylation of amphiphysin-1 by casein kinase 2 regulates clathrinamphiphysin interactions," Journal of Neurochemistry, vol. 98, no. 6, pp. 2013-2022, 2006.

[137] P. Ghosh and S. Kornfeld, "AP-1 binding to sorting signals and release from clathrin-coated vesicles is regulated by phosphorylation," Journal of Cell Biology, vol. 160, no. 5, pp. 699-708, 2003.

[138] J. Toshima, J. Y. Toshima, A. C. Martin, and D. G. Drubin, "Phosphoregulation of Arp2/3-dependent actin assembly during receptor-mediated endocytosis," Nature Cell Biology, vol. 7, no. 3, pp. 246-254, 2005.

[139] D. J. Owen, Y. Vallis, B. M. F. Pearse, H. T. McMahon, and P. R. Evans, "The structure and function of the $\beta 2$-adaptin appendage domain," EMBO Journal, vol. 19, no. 16, pp. 4216-4227, 2000.

[140] B. M. Collins, A. J. McCoy, H. M. Kent, P. R. Evans, and D. J. Owen, "Molecular architecture and functional model of the endocytic AP2 complex," Cell, vol. 109, no. 4, pp. 523-535, 2002.

[141] K. M. Turner, R. D. Burgoyne, and A. Morgan, "Protein phosphorylation and the regulation of synaptic membrane traffic," Trends in Neurosciences, vol. 22, no. 10, pp. 459-464, 1999.

[142] J. P. H. Lauritsen, C. Menné, J. Kastrup, J. Dietrich, N. Ødum, and C. Geisler, " $\beta 2$-Adaptin is constitutively dephosphorylated by serine/threonine protein phosphatase PP2A and phosphorylated by a staurosporine-sensitive kinase," Biochimica et Biophysica Acta, vol. 1497, no. 3, pp. 297-307, 2000.

[143] W. G. Paxton, M. B. Marrero, J. D. Klein, P. Delafontaine, B. C. Berk, and K. E. Bernstein, "The angiotensin II AT receptor is tyrosine and serine phosphorylated and can serve as a 
substrate for the SRC family of tyrosine kinases," Biochemical and Biophysical Research Communications, vol. 200, no. 1, pp. 260-267, 1994.

[144] H. Ohno, J. Stewart, M. C. Fournier et al., "Interaction of tyrosine-based sorting signals with clathrin-associated proteins," Science, vol. 269, no. 5232, pp. 1872-1875, 1995.

[145] D. Diviani, A. L. Lattion, L. Abuin, O. Staub, and S. Cotecchia, "The adaptor complex 2 directly interacts with the $\alpha$-adrenergic receptor and plays a role in receptor endocytosis," Journal of Biological Chemistry, vol. 278, no. 21, pp. 19331-19340, 2003.

[146] W. Hao, Z. Luo, L. Zheng, K. Prasad, and E. M. Lafer, "AP180 and AP-2 interact directly in a complex that cooperatively assembles clathrin," Journal of Biological Chemistry, vol. 274, no. 32, pp. 22785-22794, 1999.

[147] O. Cremona, G. Di Paolo, M. R. Wenk et al., "Essential role of phosphoinositide metabolism in synaptic vesicle recycling," Cell, vol. 99, no. 2, pp. 179-188, 1999. 

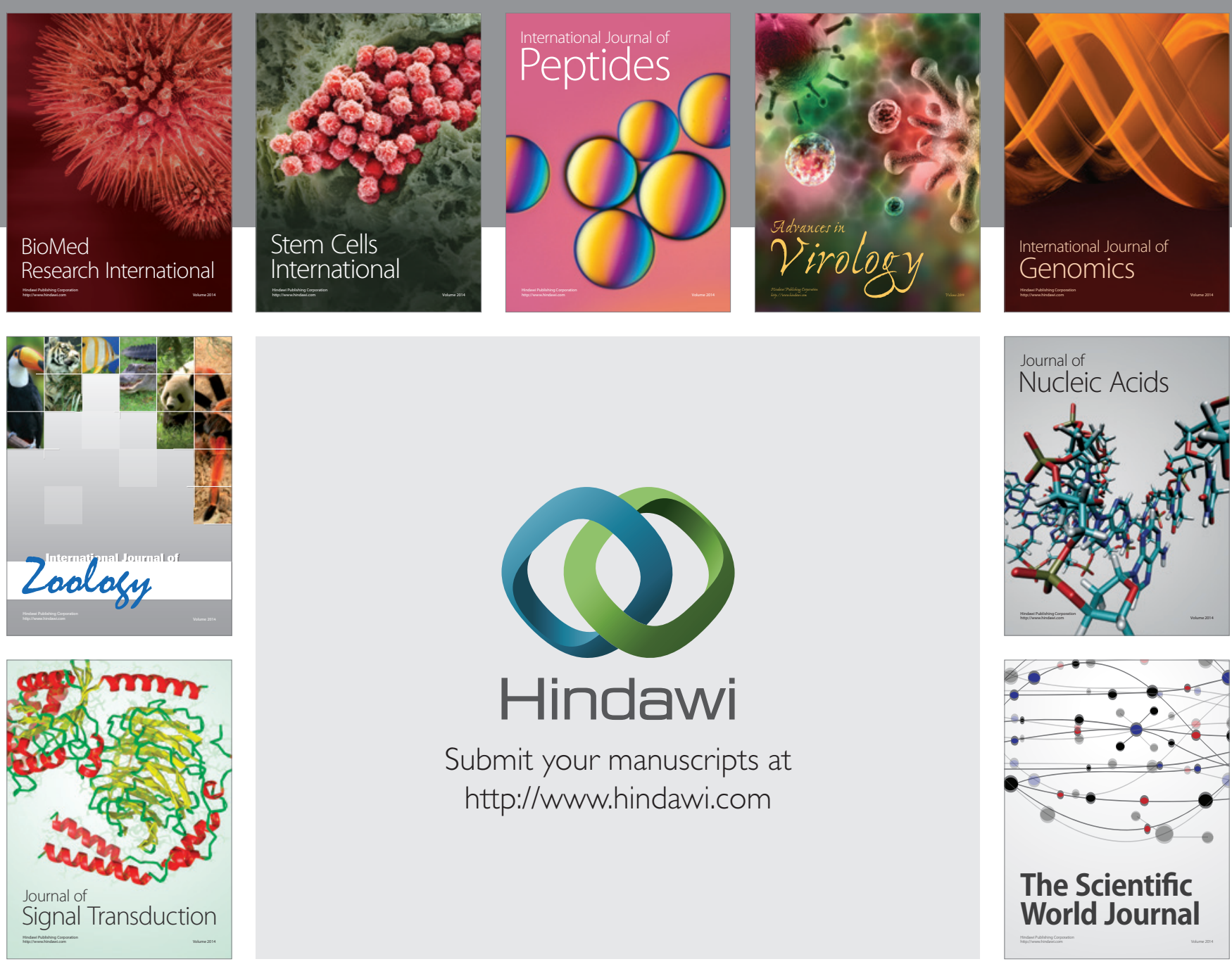

Submit your manuscripts at

http://www.hindawi.com
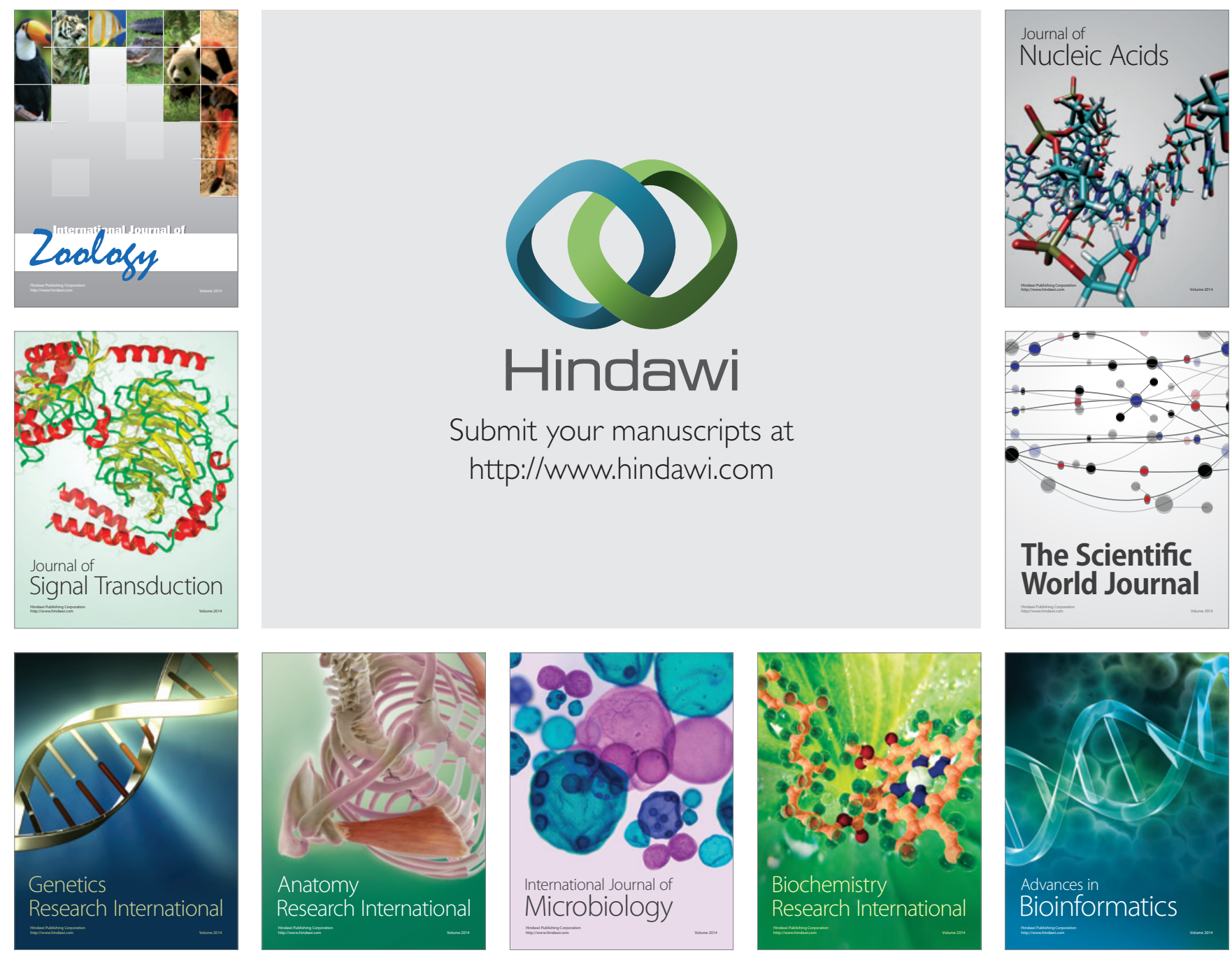

The Scientific World Journal
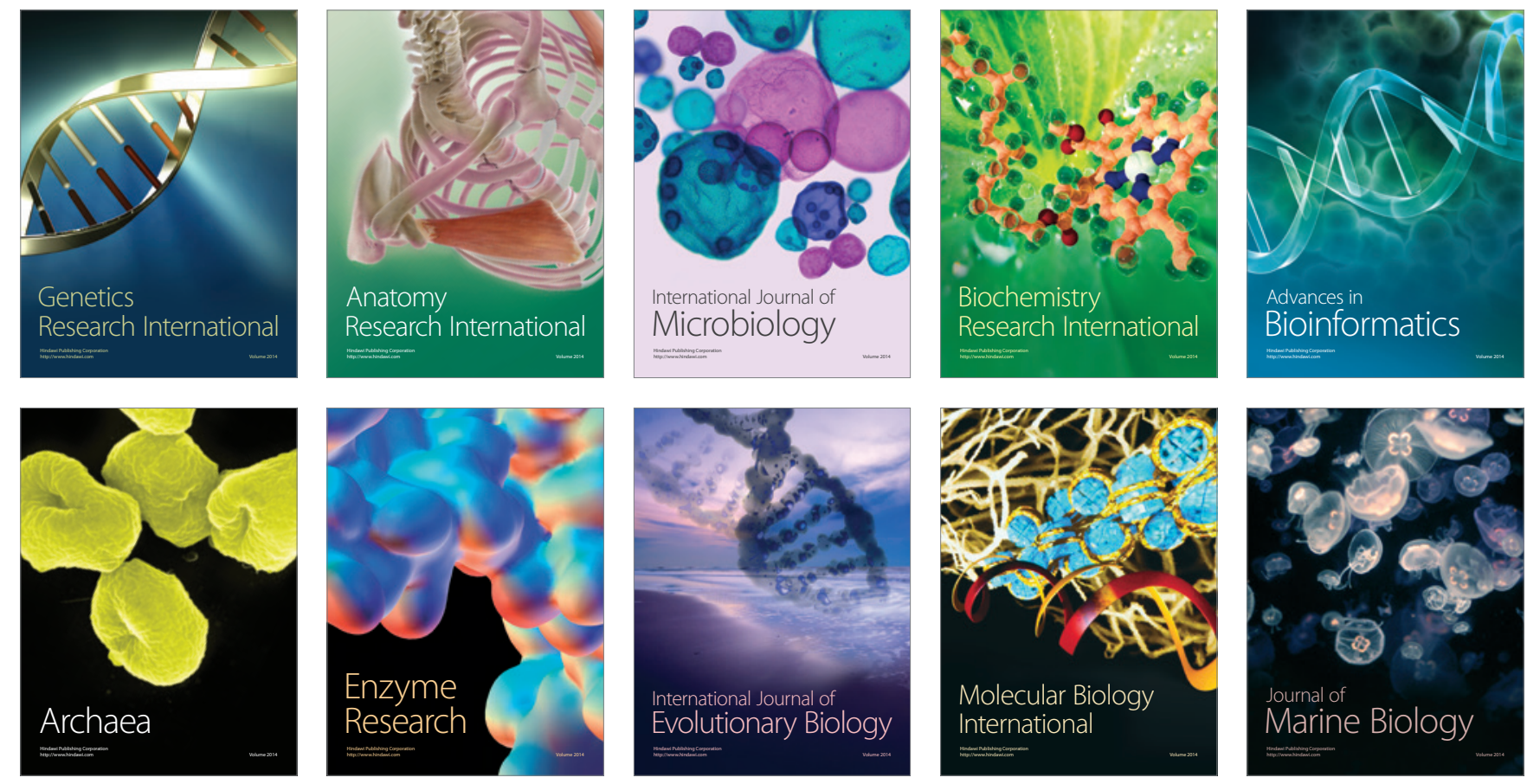